\title{
ON WELDED AND GROUTED CONNECTIONS IN OFFSHORE TUBULAR STEEL STRUCTURES
}

\author{
Inge Lotsberg \\ DNV GL, Veritasveien 1, 1322 Høvik, Norway \\ E-mail:Inge.Lotsberg@dnvgl.com
}

\begin{abstract}
This paper gives an overview of some of the most significant challenges and developments of welded and grouted connections in tubular structures subjected to dynamic loading in the North Sea the last 40 years. This includes design of tubular joints which may be designed with stubs to allow for welding from the inside and tubular joints welded from the outside only. In many structures the transition from one tubular thickness to another may be required. The development of stress concentration factor for these connections is presented. Conical connections are frequently used in framed tubular structures and some design guidance related to these together with relevant references are presented. The latest developments related to grouted connections in traditional jacket design, jackets with preinstalled piles and towers on monopiles are presented. Grouted connections are efficient to make connections of structural elements with large tolerances and for making connections below water.
\end{abstract}

Keywords: Welded connections; tubulars; grouted connections; offshore structures; dynamic loading; fatigue.

\section{Introduction}

This paper gives a short overview of some of the most significant challenges and developments of welded and grouted connections in tubular structures subjected to dynamic loading in the North Sea the last 40 years, see also Lotsberg $(2016,2019)$. The first oil platforms installed in the North Sea around 1974 were jacket structures like those in the Mexican Gulf. These structures were mainly designed with respect to the Ultimate Limit State as a good design procedure for a long-term dynamic loading and fatigue assessment had so far not been developed. However, it was realized that the environment in the North Sea was different in terms of long-term loading than that in the Mexican Gulf and research and development of design standards were started to improve the basis for a reliable design also with respect to the Fatigue Limit State. Laboratory testing was performed to develop design S-N curves for tubular joints and finite element analyses were performed to develop the first parametric equations for stress concentration factors for tubular joints. Soon a practice to design fixed platforms also with respect to the Fatigue Limit State was established (The Norwegian Petroleum Directorate, 1977, Department of Energy, 1977 and Det Norske Veritas, 1977). For floating platforms, the same methodology was not practice before after the Alexander L. Kielland accident in 1980. During the 1980s several joint industry projects were initiated to improve the design basis for welded and grouted connections. The results from these projects formed the basis for development of improved design standards for offshore structures by The Norwegian Petroleum Directorate, Health and Safety Executive (HSE) in London and Det Norske Veritas. This work was continued by the ISO organization (ISO 19902, 2007) and by NORSOK in the 1990s (NORSOK N-004, 1998 and 2013). Later further research and developments were performed which implied a continued need for revision of the design standards and design procedures to achieve more optimal structures. More optimized fabrication methods of tubular structures have also required improved design guidance as is shown in the following sections.

Tubular structures are now also being used as foundations in the sea for wind turbines. The first designs of these structures around 2002 were made as large diameter monopiles that were driven into the sea bottom. Grouted connections were used to connect the tower to theses piles. After some years it was observed that the scale effect by going from small diameter laboratory tests of the grouted connections to real structures had not been properly considered. This resulted in several repairs with significant costs, and new recommendations with respect to grouted connections had to be issued. Jacket type structures are being used to support wind turbines in deeper waters. Here grout is being used between the jacket legs and the preinstalled piles to achieve the needed connections. This has required additional laboratory testing as these connections are different from those in jacket structures in the oil and gas industry. Some of the challenges related to a sound design of these connections are presented or referred to in this paper. 


\section{Welded connections}

\subsection{Tubular joints}

Offshore steel platforms for oil and gas production are usually constructed as truss frameworks in which tubular members constitute the structural elements. The tubular members are normally connected by welding at the intersections which are denoted tubular joints. An example of a tubular joint is shown in Figure 1. This sketch gives recommended geometry with respect to analysis for static strength of the joints which was used as the main design criterion in the API standard back in the 1970s. Fatigue analyses became part of the design when jacket structures were made for the North Sea environmental conditions. This required stress concentration factors for different types of tubular joints. Significant research and development on this were made in the period from mid 1970ties to 1988 when Efthymiou published a comprehensive document on stress concentration factors for simple tubular joints which is being used today in different design standards (ISO 19902, 2007 and DNVGL-RP-C219). The tubular joints may be classified and grouped in accordance with their geometrical configuration, the action and transfer of loads, and the design types. Most tubular joints are made as simple joints which means that the joint is without additional stiffeners. Stress concentration factors for tubular joints with internal ring-stiffeners has been presented by Smedley and Fischer (1991). In some heavy-duty joints also longitudinal stiffeners are being used. However, this practice was more normal in the 1980s than in design of joints today.

For a more effective calculation of the hot spot stress at the crown position in T- and Y-joints a modified equation to that from Efthymiou (1988) has been included in DNVGL-RP-C203 (2019) as explained in Lotsberg (2011). Fatigue assessment of many jackets has been performed without considering the fluctuating stress in the chord due to the global response. However, as the design is becoming more optimized it is recommended to include also the stress range in the chord when assessing the fatigue life at the crown points in tubular joints. This is more important for support structures for wind turbines than for jacket structures which are designed for a heavy topside.

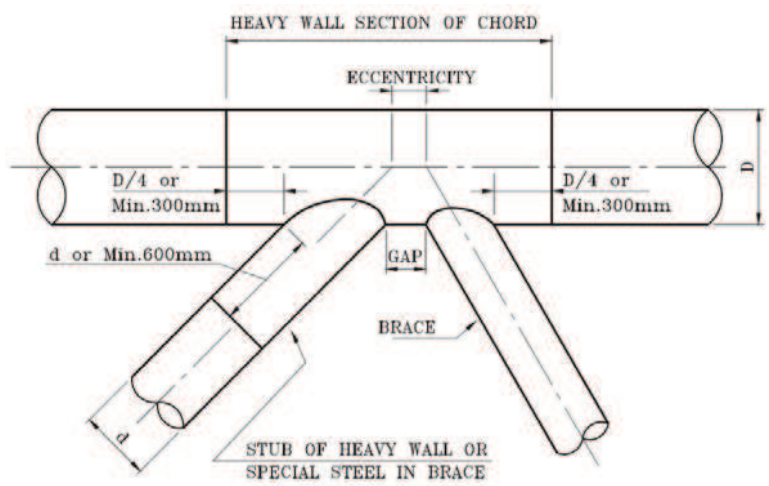

Figure 1 Requirements to geometry of tubular joints in design standards from the 1970s until today

For the most significant tubular joints in jacket structures it has been practice to using stubs as shown in Figure 1 such that welding of the joints can be performed also from the inside to achieve a weld root with good fatigue capacity. In these joints the fatigue capacity on the inside of the joints have not been an issue if fatigue assessment of the outside hot spots has been performed. More efficient fabrication and construction methods are being developed and this has resulted in a wish to use more single sided tubular joints as shown in Figure 2 to avoid the girth weld between the stub and the brace. Fatigue cracking from the weld root has not often been seen reported. A reason for this may be less tensile residual stresses after fabrication in the root than on the outside weld toe. However, with use of improvement methods on the outside hot spots it is possible to transfer larger forces through the joints and this increases also the stresses on the root side of the joints, see e.g. Qian et al. (2013). For this reason, it has been found necessary to include a design procedure also for the inside weld root in DNVGL-RPC203. This procedure is based on analyses reported by Lee et al. (1998) and Lee (1999). Reference is also made to an assessment of these results in Lotsberg et al. (2016). It should be noted that the stub lengths in Figure 1 are rather short and detailed finite element analysis of wind turbine structures has shown that there may be some interaction between the hot spot stresses at the tubular joint and the girth weld. 


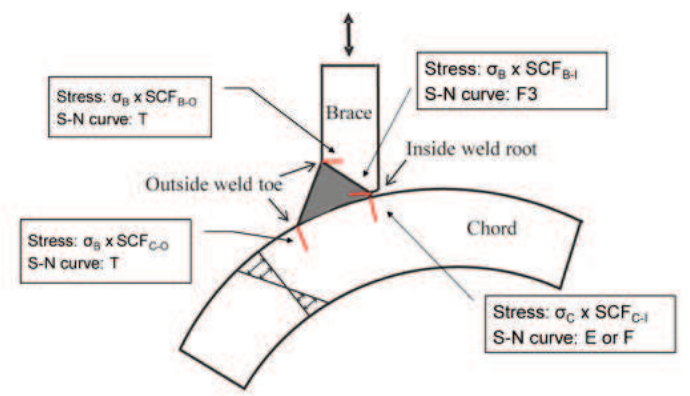

Figure 2 Potential fatigue cracks, nominal stress and SCF in simple tubular joints

$\sigma_{\mathrm{B}}=$ Nominal stress caused by brace action (resulting in stress in both chord and brace side of weld)

$\sigma_{\mathrm{C}}=$ Nominal stress caused by chord action (resulting in stress in chord side of weld only)

$\mathrm{SCF}_{\mathrm{B}-\mathrm{O}}=$ Stress Concentration Factor - Brace side - Outside (weld toe)

$\mathrm{SCF}_{\mathrm{C}-\mathrm{O}}=$ Stress Concentration Factor - Chord side - Outside (weld toe)

$\mathrm{SCF}_{\mathrm{B}-\mathrm{I}}=$ Stress Concentration Factor - Brace side - Inside (weld root)

$\mathrm{SCF}_{\mathrm{B}-\mathrm{I}}=\mathrm{SCF}_{\mathrm{B}-\mathrm{O}} \mathrm{x}$ R (if parametric equations in DNVGL-RP-C203 (2019) are used)

$\mathrm{SCF}_{\mathrm{C}-\mathrm{I}}=$ Stress Concentration Factor - Chord side - Inside (weld root)

$\mathrm{SCF}_{\mathrm{C}-\mathrm{I}}=\mathrm{SCF}_{\mathrm{C}-\mathrm{O}} \times \mathrm{R}$ (if parametric equations in DNVGL-RP-C203 are used).

$\mathrm{SCF}_{\mathrm{C}-\mathrm{I}}=1.0$ when hot spot stress analysis is used

$\mathrm{R}=$ Reduction factor of stress for inside relative to the outside from DNVGL-RP-C203.

Lack of penetration in single sided girth welds is hard to control by non-destructive examination and it is considered more difficult to detect possible defects at a root area of a tubular joint welded from one side than for a girth butt weld welded from one side. Lack of penetration in combination with other defects like lack of fusion may result in fatigue crack into the weld. This crack growth may occur in a direction normal to the main fluctuating stresses in the brace as indicated on the inside weld root in Figure 2. The fatigue design of the root area of tubular joints welded from one side may be considered as follows.

Girth welds welded from one side may be classified as F3 on the brace side, DNVGL-RP-C203 (2019). The defect size inherent in this curve is less than 1-2 mm. The F3 curve may also be considered the highest S$\mathrm{N}$ curve to be used for potential defects in the weld root growing into the weld due to stress fluctuations in the brace if a reliable non-destructive examination of this region is performed.

The size of potential defects that might grow into the chord on the weld root side is likely small and the weld to the brace may be considered like an attachment on a plate for the fluctuating stresses in the chord, i.e. that stress range in the chord can be used for fatigue analysis. This means that the E-curve can be used for brace thickness less or equal $25 \mathrm{~mm}$ and the F-curve for brace thickness larger than $25 \mathrm{~mm}$ when the stress range in the chord root is used for fatigue analysis according to DNVGL-RP-C203 (2019). If the methodology from DNVGL-RP-C203 is used for hot spot stress calculation on the chord side, the E or F curve depending on the brace thickness can be used as hot spot S-N curve. The reference thickness associated with the listed S$\mathrm{N}$ curves $\left(\mathrm{E}, \mathrm{F}\right.$ and $\mathrm{F} 3$ ) is $\mathrm{t}_{\mathrm{ref}}=25 \mathrm{~mm}$. S-N curves in air may be used for the inside weld root where the braces are filled with air. The resulting design procedure is shown in Figure 2. S-N curve T is used for fatigue assessment of the outside hot spots.

\subsection{Girth welds}

The girth welds are important for fatigue design of tethers in tension leg platforms, in jacket structures between stubs and braces and in monopiles for support of wind turbine structures, Figure 3. They are also the main welds in pipelines as shown in Figure 4.

At the end of the 1990s there was limited test data for establishing a reliable fatigue procedure for girth welds in risers and pipelines. Reference is made to Macdonald et al. (2000). The F2 curve (BS7608, 1993) was used for fatigue assessment of girth welds in structural braces welded from the outside. See also Stacey et al. (1997). This curve became also the basis for fatigue design of pipelines in NORSOK N-004 (1998). However, a slightly higher S-N curve could be used for the weld root with a small fabrication tolerance, the F1 curve. For the weld root it was assessed that a stress concentration due to fabrication tolerance equal 1.0 could be used while the stress concentration factor for the weld cap was made dependent on the actual tolerance. This was further investigated by Lotsberg and Holth (2007). Stress concentration factor for girth welds at thickness transitions and fabrication tolerances in tubulars were presented by Lotsberg (1998, 2009). The first development was based purely on shell theory. This derivation was later improved based on calibration with 
results from finite element analyses. It can be noted that the largest stress concentration is on the side with the thickness transition. The highest S-N curve applies to the outside weld toe; therefore, it is recommended that the design is performed with thickness transition on the outside as shown in Figure 3. By this methodology the stress in the weld root is less and the fatigue life in the root can still be acceptable even with a less good S-N curve.

In reassessment of structures for life extension it is found that the fatigue of girth welds in piles can be found critical when including the effect of pile driving in addition to in-service loading. Therefore, investigation was performed to improve the design basis for these connections in terms of recommended S-N curves and Design Fatigue Factors for documentation of the structural integrity, Lotsberg et al. (2010).

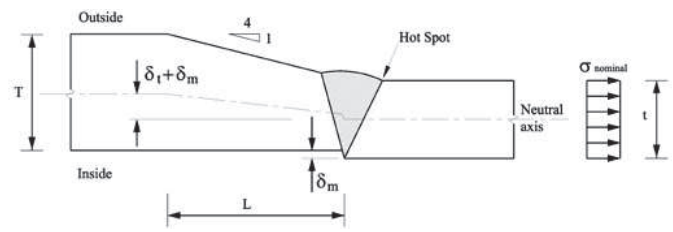

Figure 3 Typical welded transition from the stub to the brace with a transition in slope of 1:4 on the outside

The design of structures supporting wind turbines is governed by fatigue and in many of these structures very large tubular thicknesses may be needed. It is noted that the thickness effect is very different in the different design standards and that the thickness effect is an important parameter in a fatigue assessment (Lotsberg,

2014).

A significant number of full-scale fatigue tests on single side welds in risers and pipelines have been performed the last 20 years. The TWI database (Maddox and Johnston, 2011) contains 1245 full scale fatigue test results, divided into 320 root failures, 162 failures from the toe of the weld cap, 271 results from un-failed specimens that endured at least $10^{7}$ cycles, the remainder were unbroken but accumulated fewer than $10^{7}$ cycles or failed in the parent material. This has resulted in new recommendation in BS 7608 (2014) with use S-N curve E for risers and pipelines with appropriate NDT. However, it is recommended to include a stress concentration to account for fabrication tolerances. Also, the transition in slope in the S-N curve for variable amplitude loading is moved to $5 \cdot 10^{7}$ cycles in air environment. The F2 curve is still recommended for girth welds made from the outside in structural members.

A joint industry was performed by DNV GL, SINTEF and Stress Engineering in Houston for assessment of 1865 full scale tests of girth welds. The test specimens varied widely in terms of diameter (i.e. from 6 inch to $24 \mathrm{inch}$ ) and wall thickness, reeled, cladded, as welded and ground, Horn et al. (2018). This new information formed basis for use of higher S-N curves for girth welds in risers and pipelines in the 2016 version of DNVGLRP-C203. From Figure 4 it is seen that lower stress concentrations are included for the weld root than for the weld toe.

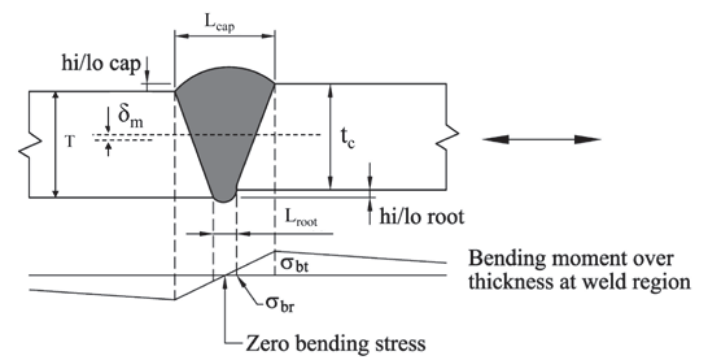

Figure 4 Calculation of stresses due fabrication tolerances in pipeline welds

\subsection{Conical connections}

The derivation of stress concentration factors for conical connections where the thickness of the cone is equal the tubular is shown in Lotsberg $(1998,2016)$. This includes also analytical expressions for conical connections with ring-stiffeners at the conical junctions. This was based on shell theory. It has later been found to be in good agreement with finite element analysis results. Analytical expressions for stress concentration factors for different thickness in the cone and the connecting tubular have been derived in Lotsberg (2018). An example of stress concentration at a cone junction in a jacket structure is shown in Figure 5. 
Geometry in example calculation: Diameter of tubular $\mathrm{D}_{1}=1430 \mathrm{~mm}$. Thickness of tubular $\mathrm{t}_{\mathrm{l}}=30 \mathrm{~mm}$, $\mathrm{t}_{2}=40 \mathrm{~mm}$,

cone angle $\alpha=8^{\circ}$.

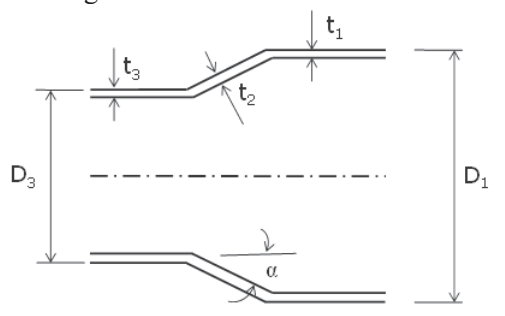

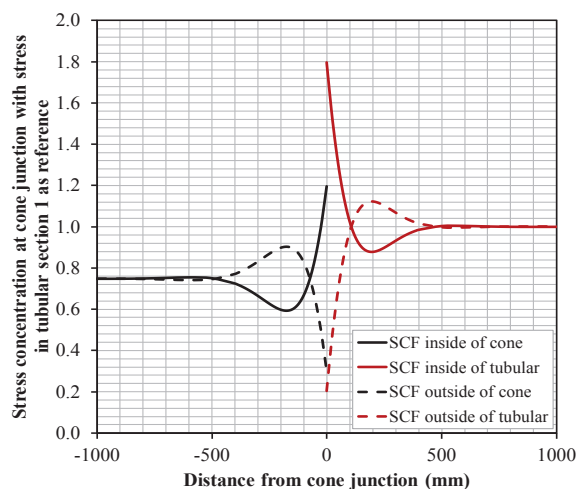

Distance from cone junction $(\mathrm{mm})$

Figure 5 Conical connection

In Lotsberg (2018) it is shown that the simplified equations for stress concentration factors at conical connections presented in design standards are to the conservative side. The conservatism increases when the thickness of the cone is increased relative to the thickness of the tubular section. It is assessed that it is not necessary to account for fabrication tolerance in design of conical connections without ring stiffeners at the junctions.

It is important to avoid unnecessary shift in neutral axis at the conical junction when there is a different thickness in the cone as compared with the tubular sections. This is more important in large diameter connections with a low cone angle than that in cones typically used in jacket structures. The thickness transition should be on the outside of the larger diameter junction and on the inside of the smaller diameter junction when thickness transitions are used.

\section{Grouted connections}

\subsection{General}

Grouted connections are being used in several different types of structures. Based on laboratory testing and inservice experience from different types of grouted connections it is observed that the actual behavior is dependent on structural geometry and type of loading. Thus, different design methodologies are required for - Grouted connections between the piles and sleeves in typical jackets for the oil and gas industry.

- Prestressed grouted connections.

- Jacket structures with preinstalled piles typically used to support wind turbines.

- Monopiles with connection to a transition piece.

\subsection{Traditional jacket structures}

Laboratory tests of an eccentric placed leg into a grouted preinstalled pile show that the moment due to this eccentricity does not significantly reduce the axial capacity if the test specimens are made with a small pile diameter as typically used in laboratory tests, Harwood et al. (1996). Due to this experience earlier design practice was to consider only the axial force in the pile in design of grouted pile to sleeve connections in jacket structures (ISO 19902, 2007). However, the moments and shear forces transferred in these connections results in a contact pressure between the steel and the grout that needs to be considered in design. For grouted connections between the piles and sleeves in typical jackets the moments and shear in the piles below the sleeve are resisted by yoke plates, braces or ring stiffeners making a concentrated contact pressure in the grout. The bending moment results in an additional shear force as shown in Figure 6 . The contact pressure is depending on the design of the grouted connections at the position of the reaction force. Two different design solutions for the force transfer between the yoke plate (or reaction plate) and the grout are shown in Figure 6 . In the left Figure $6 \mathrm{a}$ the grout is terminated above the yoke plate that is resisting the horizontal reaction $\mathrm{F}_{1}$. This result in an uneven load transfer through the grout and large stresses in the lower part of the grout. The quality of the grout close to the grout packers can also be less good. During load reversals a high contact pressure can lead to wear and cracking of the grout. Therefore, this design is not recommended where it is significant moment loading and shear load in the piles. The preferred design is shown to the right in Figure $6 \mathrm{~b}$ where the grout is extended below the yoke plate. Laboratory tests have lately been performed to improve the design basis for these connections (Johansen et al., 2018 and Marion et al., 2018). This work will provide basis for the next revision of NORSOK N-004 with respect to capacity of grouted connections in jacket structures. 


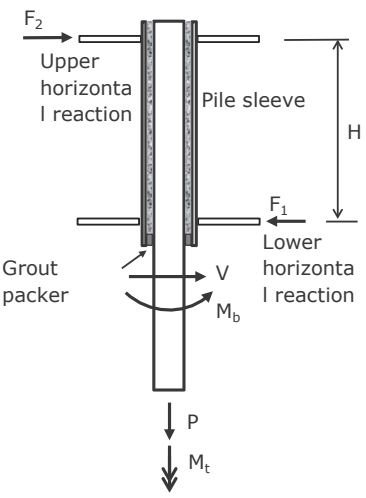

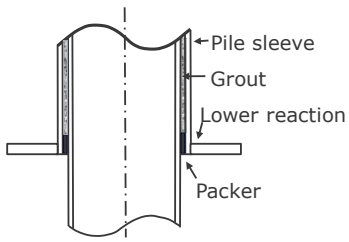

a).

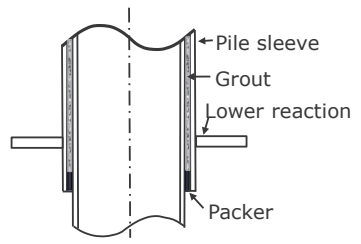

b).

Figure 6 Load transfer between pile and sleeve in traditional jacket structures

\subsection{Preinstalled piles}

Jackets with extended legs inserted into preinstalled piles are being used by the wind energy industry, see Figure 7. These grouted connections are different from that of traditional grouted connections in traditional jackets and monopiles mainly for the following reasons:

- Installation tolerances for the piles imply a significant grout thickness as compared with diameter.

- There are no shear plates.

- The loading on the connection is rather different from that on a monopile connection with relatively smaller moment loading but with larger alternating axial load.

The bending flexibility of the extended jacket leg is so large that the local reaction pressure at the top region of the grouted section may become significant. Therefore, it is considered important to determine the alternating moment with significant accuracy. Thus, reliable global analysis of the jacket including the pile with sound boundary conditions is recommended to be performed.

It is recommended to perform a finite element analysis of the grouted connection to assess the stresses in the grout. Then a fatigue assessment using S-N curves for concrete presented in DNVGL-ST-C502 (2018) can be performed. An h/s ratio of approximately 0.05 is typically recommended used in these connections with $\mathrm{s}=$ $200 \mathrm{~mm}$ as a typical distance between shear keys. The maximum requirement to radial stiffness $\mathrm{k}$ from ISO 19902 (2007) does not apply to these connections.

For installation of traditional jacket structures, it is practice to using grippers to avoid significant movement between the jacket and the pile during grout curing. To save costs in the wind industry with installation of several jackets in each windfarm the use of grippers is avoided by accepting some reduction in grout strength due to early age cycling. Some guidance on this is included in DNVGL-ST-0126 (2016). However, the allowable relative movement in this standard is small and therefore large-scale testing using relevant load histories simulating the environmental response during installation is being performed for documentation of structural capacity.

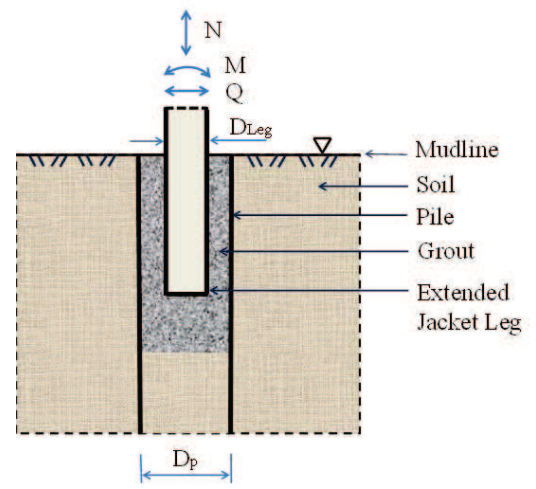

Figure 7 Grouted connection between preinstalled pile and jacket leg 


\subsection{Towers on monopiles}

A grouted connection is used to connect the transition piece to the monopile as indicated in Figure 8. A transition piece, resting on temporary supports, is installed on top of the monopile. The transition piece is then jacked up to an acceptable verticality before the grouting is carried out, thereby correcting the usual piling tolerances. After grout curing, the jacks are removed, leaving a gap between the temporary supports and the monopile. A wind turbine tower is installed on top of the transition piece.

The grouted connections in monopile structures are rather different from those of other offshore structures in terms of loading. The connections in typical jacket structures are subjected to a significant axial loading while the monopiles are subjected to a significant bending moment. The stresses in the monopile due to the bending moment from wind and wave loading can be more than one order of magnitude larger than those due to the axial load alone. Owing to the large diameter to thickness ratio, the grouted connections become rather flexible with respect to bending moment and a radial cracking of the grout may be expected. Some opening and sliding between the steel and the grout may also be expected due to the flexibility of the connection when subjected to a large bending moment.

Most of the monopile to transition piece grouted connections installed to around 2010 were plain cylindrical connections without use of shear keys. Around this time a significant number of wind towers were reported to have settled on the monopiles, coming to rest on the temporary supports. This results in a different force flow in the structure from that intended at the design stage. The unintended force transfer through temporary supports, which are not designed for permanent load cases, has led to concern about fatigue cracking in the structures and to costly repairs.

Due to this situation two joint industry projects were carried out by DNV to investigate the structural capacity of these connections from autumn 2009 to 2012. This resulted in design procedures for conical shaped grouted connections and grouted connections with shear keys which are included in DNGL-ST-0126 (2016). Reference is also made to Lotsberg et al. (2012) and Lotsberg (2013).

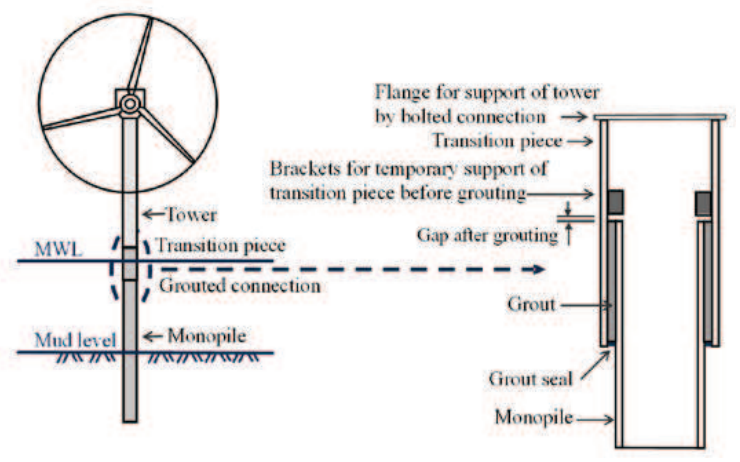

Figure 8 Principle of a grouted connection in a monopile structure

\section{References}

API RP 2A Recommended Practice for planning, designing and Constructing Fixed Offshore Platforms - Ninth edition, November 1977.

BS 7608, Code of Practice for Fatigue Design and Assessment of Steel Structures, BSI, London UK, 1993.

BS 7608, Code of Practice for Fatigue Design and Assessment of Steel Structures, BSI, London UK, 2014.

Department of Energy, Offshore installations: Guidance on Design and Construction. Second edition. UK. ISBN $0114106126,1977$.

DNV, Rules for the Design Construction and Inspection of Offshore Structures. DNV, Oslo, Norway. 1977.

DNVGL-RP-C203, Fatigue Design of Offshore Steel Structures. DNVGL, Oslo, Norway, September 2019.

DNVGL-ST-C502, Offshore Concrete Structures. DNV GL, February 2018.

DNVGL-ST-0126, Support Structures for Wind Turbines. DNV GL, April 2016.

Efthymiou, M., Development of SCF Formulae and Generalised Influence Functions for Use in Fatigue Analysis, OTJ'88 Recent Developments in Tubular Joints Technology, Surrey, UK, 1988.

Harwood, R. G, Billington, C. J., Buitrago, J., Sele, A. and Sharp, J. V., Grouted Pile to Sleeve connections: Design Provisions for the New ISO Standard for Offshore Structures. OMAE 1996, ASME, 1996.

Horn, A. M., Lotsberg, I. and Ørjasæter, O., The Rationale for Update of S-N curves for Single Sided Girth Welds for Risers and Pipelines in DNVGL-RP-C203 based on Fatigue Performance of more than 1700 Full Scale Fatigue Test Results. OMAE2018-78408. Proc. of the ASME 2018 37th Int. Conf. on Ocean, Offshore and Arctic Engineering OMAE 2018 Madrid, Spain, June 17-22, 2018. 
ISO 19902 Fixed Steel Structures. 2007.

Johansen, A. Solland, G., Lervik, A., Strande, A. and Nybø, T., Testing of Jacket Pile Sleeve Grouted Connections Exposed to Variable Axial Loads. Marine Structures, 58, 254-277, 2018.

Lee, M.K.K., Estimation of Stress Concentrations in Single-sided Welds in Offshore Tubular Joints. Int. Journal of Fatigue 21, 895-908, 1999.

Lee, M.M.K, Morgan, M. R. and Lea, F., Offshore Technology Report OTO 98044 Stress Concentrations in Single-Sided Welds in Offshore Tubular Joints, 1998.

Lotsberg, I., Fjeldstad, A. and Ronold, K. O., Background for the Revision of the DNVGL-RP-C203 Fatigue Design of Offshore Steel Structures in 2016. Proc. of the ASME 2016 35th Int. Conf. on Ocean, Offshore and Arctic Engineering OMAE2016-54939. Busan, South Korea, June 19-24, 2016.

Lotsberg, I, Serednicki, A., Bertnes, H. and Lervik, A., Design of Grouted Connections for Monopile Offshore Structures. Results from two Joint Industry Projects. Stahlbau, 81 (9) 695-704, 2012.

Lotsberg, I., Stress Concentration Factors at Circumferential Welds in Tubulars. Marine Structures, 11, 203-230, 1998.

Lotsberg, I. and Holth, P. A., Stress Concentration Factors at Welds in Tubular Sections and Pipelines. Presented at OMAE 2007. OMAE paper no 2007-29571. 26th Int. Conf. on Offshore Mechanics and Arctic Engineering, San Diego, California, June 2007.

Lotsberg, I., Stress Concentration Factors at Welds in Pipelines and Tanks subjected to Internal Pressure. Marine Structures, 21, 138-159 2008.

Lotsberg, I., Stress Concentration due to Misalignment at Butt Welds in Plated Structures and at Girth Welds in Tubulars. J. of Fatigue, 31 1337-1345, 2009.

Lotsberg, I., Wästberg, S., Ulle, H., Haagensen, P. and Hall, M. E., Fatigue Testing and S-N data for Fatigue Analysis of Piles. J. of Offshore and Arctic Engineering, 132 (4), 041602-1-7, November 2010.

Lotsberg, I., Sigurdsson, G. Arnesen, K. and Hall, M. E., Recommended Design Fatigue Factors for Reassessment of Piles subjected to Dynamic Actions from Pile Driving. J. of Offshore and Arctic Engineering, 132 (4) 041603-1-8. November 2010.

Lotsberg, I., On Stress Concentration Factors for Tubular Y- and T-joints. Marine Structures, (20), 60-69, 2011.

Lotsberg, I., Structural Mechanics for Design of Grouted Monopile Connections. Marine Structures, 32, 113-135, July 2013.

Lotsberg, I., Assessment of the Size Effect for use in Design Standards for Fatigue Analysis. J. of Fatigue, 66 86-100, 2014.

Lotsberg, I., Fatigue Design of Marine Structures. Cambridge University Press, New York, 2016.

Lotsberg, I., Design Recommendations for Conical Connections in Tubular Structures. J. of Offshore and Arctic Engineering. ASME, 141, 011604-1-7, 2018.

Lotsberg, I., Development of Fatigue Design Standards for Marine Structures. J. of Offshore and Arctic Engineering. ASME, 141, 031301-1-10, 2019.

Macdonald, K. A. Maddox, S. J. and Haagensen, P., Guidance for Fatigue Design and Assessment of Pipeline Girth Welds. HSE report, 2000.

Maddox, S. and Johnston C., Factors Affecting the Fatigue Strength of Girth Welds: An Evaluation of TWI's Resonance Fatigue Test Data Base. OMAE2011-49192. Proceedings of the ASME 2011 30th Int. Conf. on Ocean, Offshore and Arctic Engineering OMAE 2011, Rotterdam, The Netherlands, 2011.

Marion, S., Johansen, A., Solland G., Nybø, T., Testing of Jacket Pile Sleeve Grouted Connections Exposed to Shear Forces and Bending Moments. Marine Structures, 59, 401- 422, 2018.

NORSOK N-004, Design of Steel Structures, rev. 1, 1998.

NORSOK N-004, Design of Steel Structures, rev. 3, 2013.

NOU (1981), “Alexander L. Kielland” ulykken. Norges offentlige utredninger 1981:11. (In Norwegian).

NPD, Regulations for the Structural Design of Fixed Structures on the Norwegian Continental Shelf. The Norwegian Petroleum Directorate, 1977.

Smedley, S. and Fischer, P. J., Stress Concentration Factors for Ring-Stiffened Tubular Joints. Proceedings of the First International Offshore and Polar Engineering Conference, Edinburgh, 239-250. Publ. by Int. Soc. of Offshore and Polar Engineers (ISOPE), P.O.Box 1107, Golden, CO, USA, 1991.

Stacey, A., Sharp, J. V. and Nichols, N. W., Fatigue Performance of Single-sided Circumferential and Closure Welds in Offshore Jacket Structures. 1997 OMAE, ASME, 1997.

Qian, X., Petchdemaneengam, Y., Swaddiwudhipong, S., Marshall, P. Ou, Z. and Nguyen, C. T., Fatigue Performance of Tubular X-joints with PJP + welds: I -Experimental Study. Journal of Constructional Steel research 90, 49-59, 3013. 